University of Nebraska - Lincoln

DigitalCommons@University of Nebraska - Lincoln

\title{
Variation in reproductive timing for the northern long-eared myotis (Myotis septentrionalis) across Nebraska
}

\author{
Keith Geluso \\ University of Nebraska at Kearney, gelusok1@unk.edu \\ Cliff Lemen \\ University of Nebraska-Lincoln, clemen2@unl.edu \\ Patricia Freeman \\ University of Nebraska-Lincoln, pfreeman1@unl.edu \\ Brett R. Andersen \\ University of Nebraska at Kearney \\ Jeremy A. White \\ University of Nebraska at Omaha, jeremywhite@unomaha.edu
}

See next page for additional authors

Follow this and additional works at: https://digitalcommons.unl.edu/natrespapers

Part of the Natural Resources and Conservation Commons, Natural Resources Management and Policy Commons, and the Other Environmental Sciences Commons

Geluso, Keith; Lemen, Cliff; Freeman, Patricia; Andersen, Brett R.; White, Jeremy A.; and Johnson, Heather M., "Variation in reproductive timing for the northern long-eared myotis (Myotis septentrionalis) across Nebraska" (2019). Papers in Natural Resources. 1073.

https://digitalcommons.unl.edu/natrespapers/1073

This Article is brought to you for free and open access by the Natural Resources, School of at DigitalCommons@University of Nebraska - Lincoln. It has been accepted for inclusion in Papers in Natural Resources by an authorized administrator of DigitalCommons@University of Nebraska - Lincoln. 


\section{Authors}

Keith Geluso, Cliff Lemen, Patricia Freeman, Brett R. Andersen, Jeremy A. White, and Heather M. Johnson 


\title{
Variation in reproductive timing for the northern long-eared myotis (Myotis septentrionalis) across Nebraska
}

\author{
Keith Geluso ${ }^{1}{ }^{*}$, Cliff A. Lemen ${ }^{2}$, Patricia W. Freeman ${ }^{3}$, Brett R. Andersen ${ }^{1,5}$, \\ Jeremy A. White ${ }^{4}$, And Heather M. Johnson ${ }^{1}$ \\ ${ }^{1}$ Department of Biology, University of Nebraska at Kearney, Kearney, NE 68849 \\ 23210 Dudley Street, Lincoln, NE 68503 \\ ${ }^{3}$ School of Natural Resources and University of Nebraska State Museum, \\ University of Nebraska-Lincoln, Lincoln, NE 68583 \\ ${ }^{4}$ Department of Biology, University of Nebraska at Omaha, Omaha, NE 68182 \\ 5 Present address: Department of Biological Sciences, Texas Tech University, Lubbock, TX 79409
}

\begin{abstract}
The northern long-eared myotis (Myotis septentrionalis), a federally threatened species, occurs in extreme northern, eastern, and southern Nebraska. These regions vary in climate due to geographic location, topography, and elevation. During a 1-week period in early July 2015, we surveyed bats across the state and observed striking variation in the reproductive status for M. septentrionalis. We examined whether or not growing degree days, an abiotic climatic factor used mainly for agricultural practices, was associated with this reproductive variation in a mammalian species. In early July, we captured only pregnant females in the Pine Ridge region of northwestern Nebraska, the region with the lowest number of growing degree days. In contrast, we captured both lactating females and flying young along the Republican River in south-central Nebraska near the border with Kansas, an area with a high, but intermediate number of growing degree days. Along the Missouri River, in extreme east-central Nebraska, along the border with Iowa, we documented lactating females with no evidence of volant young. This locality had the highest number of growing degree days. Phenotypic plasticity in timing of births for M. septentrionalis appears to be, in part, related to climatic differences across Nebraska, a relationship commonly observed for plants and invertebrates. Our study demonstrates that reproductive phenology can vary significantly across the distribution of a species and needs to be considered when making management decisions for imperiled species. Delayed reproduction in cooler regions of the species' range presents risks to reproductive female $M$. septentrionalis and their nonvolant offspring, even with current protective measures. In areas with short growing seasons, restrictions on the timing of tree-cutting should be expanded beyond 31 July in more northerly parts of the species' distribution, so as not to hinder reproductive success during the time when juvenile bats are unable to fly.
\end{abstract}

Resumen.-El murciélago de orejas largas del norte (Myotis septentrionalis) una especie amenazada, se distribuye en los extremos norte, este y sur de Nebraska. El clima en estas regiones varía debido a la ubicación geográfica, la topografía y la elevación. Durante un período de una semana, a principios de julio del 2015, muestreamos murciélagos en todo el estado y observamos una notable variación en el estado reproductivo de M. septentrionalis. Analizamos, si el aumento en la temperatura diaria (factor climático abiótico utilizado principalmente en prácticas agrícolas) se asoció con la variación reproductiva en esta especie de mamíferos. A principios de julio, sólo capturamos hembras preñadas en la región de Pine Ridge al noroeste de Nebraska, una región con el menor número de días con aumento en la temperatura. Por el contrario, capturamos hembras lactantes y crías volando a lo largo del río Republican en el extremo centro-sur de Nebraska, cerca de la frontera con Kansas, un área con un alto pero intermitente aumento en la temperatura diaria. A lo largo del río Missouri, en el extremo este-central de Nebraska, y a lo largo de la frontera con Iowa, documentamos hembras lactantes sin evidencia de volantones. Esta localidad mostró el valor más alto de aumento en la temperatura diaria. La plasticidad fenotípica al momento del nacimiento de un $M$. septentrionalis pareciera estar, en parte, relacionada a las diferencias climáticas de Nebraska, una relación comúnmente observada en plantas e invertebrados. Nuestro estudio demuestra que la fenología reproductiva puede variar significativamente a través de la distribución de la especie, factor que debe ser considerado en el momento de tomar decisiones relacionadas al control y a las medidas de preservación de especies en peligro de extinción. En las regiones más frías del rango de distribución de la especie se observó una reproducción retrasada, siendo esto un riesgo para la hembra reproductora y sus crías no voladoras, incluso con las medidas de protección actuales. En las áreas con temporadas de cultivo cortas, las restricciones en cuanto a la tala de árboles deberían extenderse más allá del 31 de julio en las partes más al norte de su distribución, con el fin de no obstaculizar el éxito reproductivo durante el período en que los murciélagos jóvenes no pueden volar.

*Corresponding author: gelusok1@unk.edu

orcid.org/0000-0002-7606-791X 
Because of pervasive population declines due to white-nose syndrome (WNS) in the eastern United States, the northern long-eared myotis (Myotis septentrionalis) was recently designated as threatened under the Endangered Species Act (Moosman et al. 2013, USFWS 2013, 2015). The fungus that causes WNS, Pseudogymnoascus destructans, has continued to spread westward across North America, with observations now beyond the Great Plains in western South Dakota, eastern Wyoming, and Washington (www.whitenose syndrome.org). Due to recent declines, a number of protective measures were established that provide for the conservation of the species, including restrictions that limit tree-cutting in areas where $M$. septentrionalis is known to bear and raise young (USFWS 2015). Risk of injury or death can occur when a roost tree is felled, especially when young bats cannot fly (USFWS 2015). To date, little is known about the variation in reproductive timing, and whether or not protective measures encompass the entire reproductive period of $M$. septentrionalis in summer throughout its widespread distribution. In southerly parts of the distribution of $M$. septentrionalis, females generally give birth between mid-May and mid-June, whereas parturition occurs later in northerly parts of the distribution (Caceres and Barclay 2000).

In the United States, M. septentrionalis reaches its westernmost distributional limits in the Great Plains (Caceres and Barclay 2000, USFWS 2015). In Nebraska, the species occurs in extreme northern, eastern, and southern parts of the state (Czaplewski et al. 1979, Benedict 2004, White et al. 2016, Johnson and Geluso 2017). This unusual distribution appears to be related to a combination of forests and rocky habitats required for hibernation (Lemen et al. 2016). In summer, reproduction occurs in all 3 regions of Nebraska (Benedict 2004). During a 1-week period in early July 2015, we surveyed bats across the state and observed variation in the reproductive status of $M$. septentrionalis. These 3 regions vary in climate due to geographic location, regional topography, and elevation.

Herein, we examined whether an abiotic factor associated with climate helped to explain differences in the reproductive phenology of M. septentrionalis. Growing degree days (GDD) is a heat unit typically used for agricultural purposes, but such a metric can also be used to understand the timing of biological processes such as hatch or birth date in animals (Trudgill et al. 2005). Poikilothermic species, such as plants and invertebrates, rely on ambient temperatures above a specific base temperature $\left(\mathrm{T}_{\text {base }}\right)$ to initiate and continue growth. Simply stated, GDD is a cumulative measure of accumulated heat in the environment that can be related to overall development of organisms, such as date of flowering and maturity of fruits in plants or date of emergence and molting stages in invertebrates. We predicted that total GDD from 1 January to 30 June 2015 would be associated with the reproductive status of the northern long-eared myotis in early July 2015 in different regions of Nebraska.

We conducted this study at 3 sites across Nebraska. In northwestern Nebraska, we captured bats along Larrabee Creek at an elevation of $1043 \mathrm{~m}$, near the eastern edge of the Pine Ridge in Sheridan County (Geluso et al. 2015). Uplands generally contained forests of ponderosa pine (Pinus ponderosa) and grasslands grazed by livestock. Along the creek, numerous plains cottonwoods (Populus deltoides), box elder (Acer negundo), green ash (Fraxinus pennsylvanica), and willows (Salix spp.) formed a narrow corridor of deciduous trees. In south-central Nebraska, near the border with Kansas, we captured bats at an elevation of $521 \mathrm{~m}$ along Elm Creek, a tributary of the Republican River, in Webster County (Elm Creek State Wildlife Management Area). We captured the bats under the canopy of dense deciduous trees in forested areas and above the creek. Dominant trees in the lowland forest consisted of common hackberry (Celtis occidentalis), mulberry (Morus spp.), and American elm (Ulmus americana). In extreme eastcentral Nebraska, along the border with Iowa, we captured bats along a stream and over trails in the floodplain of the Missouri River at an elevation of $297 \mathrm{~m}$ in Sarpy County (Fontenelle Forest, a private conservation association; Geluso et al. 2004). The stream site was at the edge of a lowland forest, and the trail sites were under the forest canopy. The forest was dominated by plains cottonwoods, American sycamore (Platanus occidentalis), common hackberry, roughleaf dogwood (Cornus drummondii), box elder, and mulberry.

We captured bats by deploying mist nets of various sizes (Avinet, Inc., Portland, ME), 


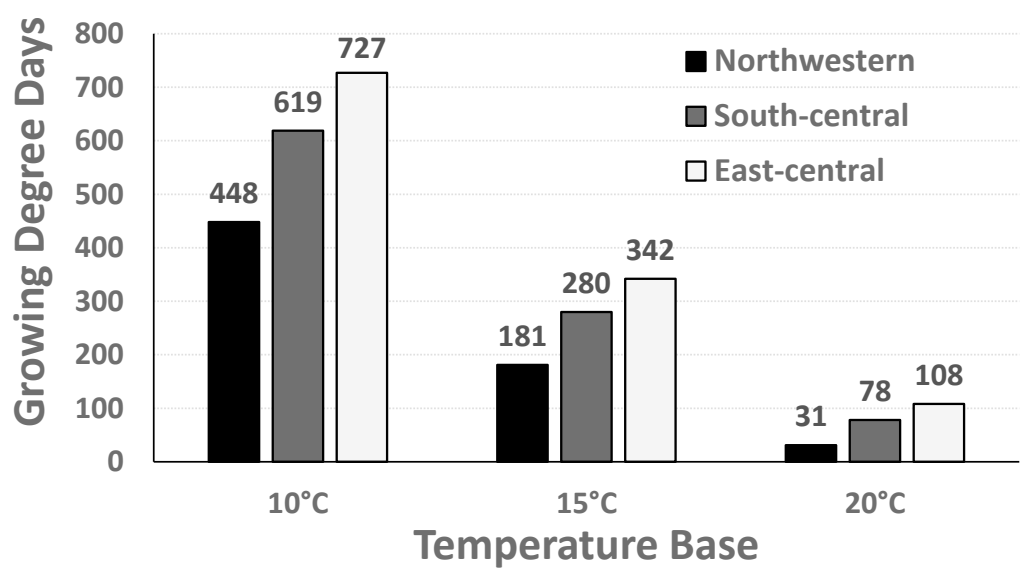

Fig. 1. Growing degree days $\left({ }^{\circ} \mathrm{C}\right)$ from 1 January 2015 to 30 June 2015 from 3 regions of Nebraska, where reproductively active female northern long-eared myotis (Myotis septentrionalis) were observed. In northwestern Nebraska, females were pregnant in early July; in east-central Nebraska, bats were lactating; and in south-central Nebraska, volant young and lactating females were observed.

mainly above small streams, but we set a few nets on trails and in open forest understory. Nets were set prior to dusk and monitored for a few hours after sunset. For each individual captured, we recorded the species, sex, weight, forearm length, age (adult or volant young), and reproductive condition for adult females (pregnant, lactating, and postlactating). We assessed pregnancy by gentle palpitation of the abdominal region, to feel for the hard region associated with the fetus that cannot be located if the stomach is distended only due to food. Lactation was determined only if milk could be expressed; postlactation was determined if milk could not be expressed, but hair around the nipple was worn or absent. Individuals were released at capture sites and temporarily marked with ink on a wing so recaptures were not recorded twice.

We amassed GDD for each netting site from a nearby weather station: Pine Ridge Airport, South Dakota, for the Sheridan County locality in northwestern Nebraska; Red Cloud in south-central Nebraska; and Omaha Eppley Airfield in east-central Nebraska (accessed from High Plains Regional Climate Center; http://climod.unl.edu/). We used temperature base $10{ }^{\circ} \mathrm{C}\left(50^{\circ} \mathrm{F}\right)$, which is commonly used in GDD, as well as temperature base $15^{\circ} \mathrm{C}\left(59^{\circ} \mathrm{F}\right)$ and $20{ }^{\circ} \mathrm{C}\left(68{ }^{\circ} \mathrm{F}\right)$. Base temperature $\left(\mathrm{T}_{\text {base }}\right)$ is defined as the lower temperature limit for organismal growth and development, which varies among species due to environmental adaptations (Trudgill et al. 2005). We suspected that female bats might enter torpor at higher temperatures than $10{ }^{\circ} \mathrm{C}$, so this $\mathrm{T}_{\text {base }}$ might not have been the most appropriate for this heterothermic endotherm. Wolbert et al. (2014) demonstrated in Pennsylvania that bat activity began to increase with ambient temperatures above $10{ }^{\circ} \mathrm{C}$, with the highest levels of activity at about $18{ }^{\circ} \mathrm{C}$. Moreover, those authors showed that a large proportion of insect samples below $20{ }^{\circ} \mathrm{C}$ yielded few to no insects, whereas all samples above $22{ }^{\circ} \mathrm{C}$ contained insects (Wolbert et al. 2014). Reynolds (2006) showed that temperature had a strong effect on bat activity, with a mean maximum temperature of $24{ }^{\circ} \mathrm{C}$ for high bat activity, and $9.8^{\circ} \mathrm{C}$ for days with no bat activity. We summed the total GDD from 1 January 2015 to 30 June 2015 for each region from each nearby weather station. GDD is reported in degrees Celsius.

In east-central Nebraska, we captured 1 lactating female $M$. septentrionalis on 1 July 2015 and 3 lactating females on 6 July 2015. On 2 July 2015, we captured 4 pregnant females in northwestern Nebraska. On 4 July 2015, we captured 1 lactating female and 2 volant young-of-year in south-central Nebraska. Values of amassed GDD were highest in east-central Nebraska, intermediate in southcentral Nebraska, and lowest in northwestern Nebraska (Fig. 1). GDD at the northwestern site compared to the total (maximum) GDD of 
east-central Nebraska was $62 \%$ at $\mathrm{T}_{10}, 53 \%$ at $\mathrm{T}_{15}$, and $29 \%$ at $\mathrm{T}_{20}$. GDD at the southcentral site compared to the maximum GDD of east-central Nebraska was $85 \%$ at $\mathrm{T}_{10}, 82 \%$ at $\mathrm{T}_{15}$, and $72 \%$ at $\mathrm{T}_{20}$.

We predicted that our south-central site with volant young, the most advanced reproductive stage, would have the highest GDD. However, we observed that the site in eastcentral Nebraska had the greatest GDD. The south-central site had about $85 \%$ of the GDD of eastern Nebraska. One possible explanation for this pattern is that females in southern Nebraska roosted in human-made structures and accelerated embryonic development. Myotis septentrionalis is known to form maternity colonies in buildings, including in Nebraska (Whitaker et al. 2006, Stein and White 2016). Additionally, actual GDD at roost sites might not reflect GDD at weather stations. Lastly, we might have failed to detect flying young in eastern Nebraska when they were actually present. As predicted, values of GDD in northwestern Nebraska were considerably lower than those in east-central and south-central sites, especially as $\mathrm{T}_{\text {base }}$ increased. Values of GDD in the east-central and south-central sites, the 2 warmest sites with the most advanced reproductive stages, were most similar across $\mathrm{T}_{\text {base }}$. Our capture of pregnant females on 2 July in Sheridan County greatly extends the period of pregnancy for this species in Nebraska. The previous latest date of pregnancy recorded in the state was 31 May (Geluso et al. 2004).

In Nebraska, researchers have reported previously on variation in the reproductive timing of M. septentrionalis, as well as in other bat species across the state, from an accumulation of decades of fieldwork (e.g., Czaplewski et al. 1979, Benedict 2004, Geluso et al. 2013, Johnson and Geluso 2017). For M. septentrionalis in Nebraska, the previously known period of pregnancy was 19 May to 31 May (Geluso et al. 2004), lactation 31 May to 1 August (Geluso et al. 2004 and Benedict 2004, respectively), and volant young 3 July to 5 September (Geluso et al. 2004). Such ranges in dates for the different reproductive stages are usually associated with year-to-year variation in weather. Prolonged rainy periods, or cooler weather in late spring and early summer, delays reproduction in bats (Humphrey et al. 1977, Racey and Swift 1981, Audet and
Fenton 1988, Grindal et al. 1992, Lewis 1993, Ransome and McOwat 1994). Other studies have reported reproductive delays directly associated with low food availability (Arlettaz et al. 2001).

This study demonstrated that within a single reproductive season, variation in timing of reproductive events also relates to geographic location, even over a relatively short distance. Variation in reproductive timing for M. septentrionalis in Nebraska appeared related, in part, to thermal time measured by GDD. In regions with more heat and higher GDD, M. septentrionalis had more advanced reproductive growth and development, thus earlier dates for reproductive events such as parturition, lactation, and volant young. In northwestern Nebraska, where temperatures were considerably cooler and values of GDD were lowest, individuals had delayed reproductive growth and development, and had later dates for reproductive events. Our study helps to provide additional context for variation shown in summaries of dates for the reproductive timing of bats.

Most bats are heterothermic; that is, individual bats can maintain internally high body temperatures and allow internal body temperatures to drop when environmental conditions are unfavorable (Hill and Smith 1984, Altringham 1996). A lowered body temperature of females in response to colder conditions or lack of food during pregnancy slows growth rates of young (Racey 1973, Racey and Swift 1981, Lewis 1993). To promote embryonic growth and reduce metabolic costs, reproductively active females commonly select roosts that remain warm, such as buildings $(\mathrm{McNab}$ 1982, Lausen and Barclay 2006, Geluso and Best 2017). Additionally, in mountainous regions, females tend to reside in lower elevations with warmer temperatures and greater insect abundance in order to maximize reproductive growth rates (Cryan et al. 2000). For bat species occurring over a large geographic region, such as M. septentrionalis, heterothermy appears to contribute to variation in timing of reproductive events. GDD can be used to examine phenology of developmental rates for plants and poikilothermic animals, such as invertebrates (Trudgill et al. 2005, Forrest and Miller-Rushing 2010). Bats, however, are likely one of the few endothermic organisms where GDD can relate to development, as 
their heterothermic abilities enable individuals to lower body temperatures on a daily basis if local conditions are unfavorable. Racey (1973) demonstrated that length of gestation in heterothermic bats can be profoundly influenced by environmental conditions.

The northern long-eared myotis occurs from the eastern and southeastern United States to northwestern Canada (Caceres and Barclay 2000, USFWS 2015). After population declines, protective measures were established to provide for the conservation of M. septentrionalis throughout its widespread distribution (USFWS 2015). One such measure included limiting tree-cutting from 1 June to 31 July in areas with maternity colonies, when juvenile bats are unable to fly (USFWS 2015). Our study demonstrates that reproductive phenology can vary across the distribution of a species, even dramatically within a single state, and needs to be accounted for when management decisions are made for imperiled species. Known published dates for parturition range from as early as 10 May in Louisiana in southern parts of M. septentrionalis distribution (Crnkovic 2003) to 20 July in New Brunswick, Canada, in northeastern parts of the distribution (Broders et al. 2006). Known dates of lactation can extend into early August in northern Nebraska (Benedict 2004) and mid-August in Wyoming (Geluso and Bogan 2018). In these cooler regions of the species' distribution, individuals are likely challenged to store sufficient quantities of fat reserves to ensure survival while hibernating through winter. Rangewide protections for the species may not currently encompass the entire reproductive period of M. septentrionalis in cooler regions of its range, where delayed reproduction occurs. Restrictions on the timing of tree-cutting should be expanded in more northerly parts of M. septentrionalis distribution so as not to hinder reproductive success in areas with short growing seasons.

\section{ACKNOWLEDGMENTS}

We thank J. Brownlow, the Fontenelle Forest Association, and the Nebraska Game and Parks Commission for access to their lands. Our research in the Pine Ridge region of Nebraska was funded through the Nebraska Game and Parks Commission, State Wildlife Grant program.

\section{Literature Cited}

ALtringham, J.D. 1996. Bats: biology and behavior. Oxford University Press, Oxford, United Kingdom.

Arlettaz, R., P. Christe, A. Lugon, N. Perrin, and P. VogEL. 2001. Food availability dictates the timing of parturition in insectivorous mouse-eared bats. Oikos 95:105-111.

Audet, D., And M.B. Fenton. 1988. Heterothermy and the use of topor by the bat Eptesicus fuscus (Chiroptera: Vespertilionidae): a field study. Physiological Zoology 61:197-204.

BEnEDiCT, R.A. 2004. Reproductive activity and distribution of bats in Nebraska. Western North American Naturalist 64:231-248.

Broders, H.G., G.J. Forbes, S. Woodley, and I.D. Thompson. 2006. Range extent and stand selection for roosting and foraging in forest-dwelling northern long-eared bats and little brown bats in the Greater Fundy Ecosystem, New Brunswick. Journal of Wildlife Management 70:1174-1184.

Caceres, M.C., AND R.M.R. BarClay. 2000. Myotis septentrionalis. Mammalian Species 634:1-4.

Crnkovic, A.C. 2003. Discovery of northern long-eared myotis, Myotis septentrionalis (Chiroptera: Vespertilionidae), in Louisiana. Southwestern Naturalist 48: $715-717$.

Cryan, P.M., M.A. Bogan, and J.S. Altenbach. 2000. Effect of elevation on distribution of female bats in the Black Hills, South Dakota. Journal of Mammalogy 81:719-725.

Czaplewski, N.J., J.P. Farney, J.K. Jones JR., and J.D. DrueCKer. 1979. Synopsis of bats of Nebraska. Occasional Papers, Museum Texas Tech University 61: $1-24$.

Forrest, J., AND A.J. Miller-Rushing. 2010. Toward a synthetic understanding of the role of phenology in ecology and evolution. Philosophical Transactions of the Royal Society of London Series B, Biological Sciences 365:3101-3112.

Geluso, K.N., R.A. Benedict, and F.L. Kock. 2004. Seasonal activity and reproduction in bats of eastcentral Nebraska. Transactions of the Nebraska Academy of Sciences 29:33-44.

Geluso, K.N., AND T.L. Best. 2017. Selection of a remote maternity roost by fringed myotis (Myotis thysanodes) in Carlsbad Cavern, New Mexico. Southwestern Naturalist 62:113-120.

Geluso, K., And M.A. Bogan. 2018. Bats in the Bear Lodge Mountains and surrounding areas in northeastern Wyoming. Occasional Papers, Museum of Texas Tech University 355:1-17.

Geluso, K., J.J. Huebschman, and K.N. Geluso. 2013. Bats of the Wildcat Hills and surrounding areas in western Nebraska. Monographs of the Western North American Naturalist 6:20-42.

Geluso, K., C.A. Lemen, and P.W. Freeman. 2015. Current status of the northern long-eared myotis (Myotis septentrionalis) in northwestern Nebraska. Transactions of the Nebraska Academy of Sciences 35:34-40.

Grindal, S.D., T.S. Collard, R.M. Brigham, and R.M.R. BARCLAY. 1992. The influence of precipitation on reproduction by Myotis bats in British Columbia. American Midland Naturalist 128:339-344.

HiLl, J.E., AND J.D. SMITH. 1984. Bats: a natural history. University of Texas Press, Austin, TX. 243 pp. 
Humphrey, S.R., A.R. Richter, and J.B. Cope. 1977. Summer habitat and ecology of the endangered Indiana bat, Myotis sodalis. Journal of Mammalogy 58: 334-346.

Johnson, O.J., And K. Geluso. 2017. Distributional and reproductive records of bats from south-central Nebraska. Occasional Papers, Museum of Texas Tech University 347:1-15.

Lausen, C.L., AND R.M.R. BarClay. 2006. Benefits of living in a building: big brown bats (Eptesicus fuscus) in rocks versus buildings. Journal of Mammalogy 87: 362-370.

Lemen, C.A., P.W. Freeman, and J.A. White. 2016. Acoustic evidence of bats using rock crevices in winter: a call for more research on winter roosts in North America. Transactions of the Nebraska Academy of Sciences 36:9-13.

LEWIS, S.E. 1993. Effect of climatic variation on reproduction by pallid bats (Antrozous pallidus). Canadian Journal of Zoology 71:1429-1433.

MCNAB, B.K. 1982. Evolutionary alternatives in the physiological ecology of bats. Pages 151-200 in T.H. Kunz, editor, Ecology of bats, Plenum Press, New York, NY.

Moosman, P.R., JR., J.P. Veilleux, G.W. Pelton, and H.H. Thomas. 2013. Changes in capture rates in a community of bats in New Hampshire during the progression of white-nose syndrome. Northeastern Naturalist 20:552-558.

RACEY, P.A. 1973. Environmental factors affecting the length of gestation in heterothermic bats. Journal of Reproduction and Fertility. Supplements 19:175-189.

RaCEY, P.A., AND S.M. SWIFT. 1981. Variations in gestation length in a colony of pipistrelle bats (Pipistrellus pipistrellus) from year to year. Journal of Reproduction and Fertility 61:123-129.

Ransome, R.D., and T.P. McOwat. 1994. Birth timing and population changes in greater horseshoe bat colonies (Rhinolophus ferrumequinum) are synchronized by climatic temperature. Zoological Journal of the Linnean Society 112:337-351.
REynolds, D.S. 2006. Monitoring the potential impact of a wind development site on bats in the Northeast. Journal of Wildlife Management 70:1219-1227.

Trudgill, D.L., A. HoneK, D. LI, and N.M. VAN STRAalen. 2005. Thermal time - concepts and utility. Annals of Applied Biology 146:1-14.

SteIn, R.M., AND J.A. White. 2016. Maternity colony of northern long-eared myotis (Myotis septentrionalis) in a human-made structure in Nebraska. Transactions of the Nebraska Academy of Sciences 36:1-5.

[USFWS] United States Fish and Wildlife SERVice. 2013. Endangered and threatened wildlife and plants; 12-month finding on a petition to list the eastern small-footed bat and the northern longeared bat as endangered or threatened species; listing the northern long-eared bat as an endangered species. Federal Register 78:61046-61080.

[USFWS] United States Fish and Wildlife Service. 2015. Endangered and threatened wildlife and plants; threatened species status for the northern long-eared bat with 4(d) rule. Federal Register 80: 17974-18033.

Whitaker, J.O., JR., D.W. Sparks, and V. Brack Jr. 2006. Use of artificial roost structures by bats at the Indianapolis International Airport. Environmental Management 38:28-36.

White, J.A., C.A. Lemen, and P.W. Freeman. 2016. Acoustic detection reveals fine-scale distributions of Myotis lucifugus, Myotis septentrionalis, and Perimyotis subflavus in eastern Nebraska. Western North American Naturalist 76:27-35.

Wolbert, S.J., A.S. Zellner, AND H.P. Whidden. 2014. Bat activity, insect biomass, and temperature along an elevational gradient. Northeastern Naturalist 21: $72-85$.

Received 19 January 2019

Revised 8 June 2019

Accepted 27 June 2019

Published online 10 December 2019 